\title{
A mikro-RNS-ek szerepe az agyalapimirigy-daganatok tumorbiológiájában
}

\author{
Németh Kinga $^{1}$ - Darvasi Ottó ${ }^{2}$ - Szücs Nikolette dr. ${ }^{1}$ \\ Czirják Sándor dr. ${ }^{3}$. Butz Henriett dr. ${ }^{2,4}$ \\ 'Semmelweis Egyetem, Általános Orvostudományi Kar, II. Belgyógyászati Klinika, Budapest \\ ${ }^{2}$ Magyar Tudományos Akadémia-Semmelweis Egyetem, \\ „Lendület” Örökletes Endokrin Daganatok Kutatócsoport, Budapest \\ ${ }^{3}$ Országos Klinikai Idegtudományi Intézet, Budapest \\ ${ }^{4}$ Semmelweis Egyetem, Laboratóriumi Medicina Intézet, Budapest
}

\begin{abstract}
A mikro-RNS-ek rövid, egyszálú RNS-molekulák, melyek szabályozó szerepüket más gének poszttranszkripcionális módosítása révén fejtik ki. A humán fehérjéket kódoló gének nagyjából 30\%-a miRNS-ek szabályozása alatt is áll, aminek révén olyan alapvető folyamatokat befolyásolnak, mint a sejtosztódás, -differenciálódás és sejthalál. Számos daganattípussal kapcsolatban írták már le a megváltozott miRNS-expressziós mintázatot, és egyre több közlemény veti fel, hogy a miRNS-ek, mint terápiás célpontok is szóba jöhetnek. A csökkent expressziójú miRNS-ek adásán, illetve az emelkedett expressziót mutató miRNS-ek gátlásán keresztül nem csak egyetlen gén, hanem egész jelátviteli útvonalak befolyásolása is lehetővé válhat. Az agyalapimirigy-daganatok a leggyakoribb intracranialis tumorok közé tartoznak. Gyakoriságuk ellenére a sporadikusan előforduló adenomák kialakulásának molekuláris mechanizmusa még kevéssé van feltárva. Az utóbbi években egyre több bizonyíték utal arra, hogy a mikro-RNS-eknek fontos szerepük van az adenomagenezisben. Összefoglalónkban az agyalapimirigy-adenomákban leírt miRNS-ek szerepét kívánjuk bemutatni, valamint felvázolni a miRNS-ekhez kapcsolódó terápiás lehetőségeket.
\end{abstract}

Orv Hetil. 2018; 159(7): 252-259.

Kulcsszavak: mikro-RNS, agyalapimirigy-adenoma, biomarker

\section{The role of miRNAs in the pathogenesis of pituitary adenomas}

MicroRNAs (miRNAs) are short, single stranded RNA molecules which play regulatory roles through posttranscriptional regulation of their target genes. Based on our current knowledge, more than $30 \%$ of the human protein-coding genes are regulated by miRNAs, hence influencing basic cellular mechanisms including cell proliferation, differentiation and cell death. Differential miRNA expression pattern has been detected in many different types of tumors and, recently, several publications have referred to miRNAs as potential therapeutic targets. Through adjustment of miRNA levels by artificial miRNAs administration or miRNA inhibition, we can influence not only one target gene but also complex biological pathways. Pituitary adenoma is the second most frequent intracranial tumor. In spite of this, the molecular mechanism of the pituitary adenoma formation is not yet entirely revealed. Recently, more and more evidences have been found suggesting that miRNAs have an important role in pituitary adenoma pathogenesis. Here, we summarize the recent results related to this role and highlight the therapeutic potentials in pituitary adenomas.

Keywords: microRNAs, pituitary adenoma, biomarker

Németh K, Darvasi O, Szücs N, Czirják S, Butz H. [The role of miRNAs in the pathogenesis of pituitary adenomas]. Orv Hetil. 2018; 159(7): 252-259.

(Beérkezett: 2017. augusztus 31.; elfogadva: 2017. szeptember 20.) 


\section{Rövidítések}

ACTH $=$ adrenokortikotrop hormon; AIP = aryl hydrocarbon receptor interacting protein; $\mathrm{CDC} 25 \mathrm{~A}=$ dual specificity phosphatase $\mathrm{CDC} 25 \mathrm{~A} ; \mathrm{CDKl}=$ cell division protein kinase 1 ; EGFR = epidermális növekedési faktor; FSH = folliculusstimuláló hormon; $\mathrm{GH}=$ (growth hormone) növekedési hormon; GNASI = guanine nucleotide regulatory protein (G-protein); HMGAl, 2 = high mobility group protein Al, A2; KRAS = kirsten rat sarcoma viral oncogene homolog; $\mathrm{LH}=$ luteinizáló hormon; MENl = multiplex endokrin neoplasia 1 -es típusa; miRNS $=$ mikro-RNS; $\mathrm{mRNS}=$ (messenger) hírvivő RNS; $\mathrm{NFA}=$ nem funkcionáló adenoma; PACAP = pituitary adenylate cyclase-activating polypeptide; $\mathrm{PKC}=$ proteinkináz-C; PRL = prolaktin; PTTGl = pituitary tumor-transforming 1 ; RAS = RAS-fehérjecsalád, kis GTPáz fehérjék gyüjtőneve; RB $=$ retinoblastoma tumorszuppresszor gén; RISC $=($ RNA-induced silencing complex) RNS-indukált csendesítő komplex; SMAD3, - 6, -9 = SMAD (mothers against DPP homolog [drosophila]) family member $3,6,9$; TGFß $=($ transforming growth factor $\beta)$ transzformáló növekedési faktor- $\beta$; UTR $=($ untranslated region) nem transzlálódó régió; $\mathrm{VEGFR}=$ vascularis endothelialis növekedési faktor; VIPRI-2 = vasoactiv intestinalis polipeptidreceptor-1-2; WEE1 = WEE1 G2 checkpoint kinase

A mikro-RNS-ek (miRNS-ek) rövid, egyszálú RNS-molekulák, melyek szabályozó szerepüket más gének poszttranszkripcionális módosítása révén fejtik ki. A citoplazmában a miRNS-ek az ún. RNS-indukált csendesító komplexben (RISC) a célgén mRNS-ének 3'UTR-régiójához kötődnek, és részt vesznek az mRNS fehérjére történő átíródásában $[1,2]$.

A miRNS-ek jelentőségét jól mutatja, hogy jelenlegi tudásunk szerint a humán fehérjéket kódoló gének több mint 30\%-a miRNS-ek szabályozása alatt is áll $[3,4]$.

$\mathrm{Az}$ agyalapimirigy-daganatok az intracranialis tumorok 10-25\%-át alkotva a leggyakoribb daganatok közé tartoznak [5]. Bár általában jóindulatúak, térfoglalásuk révén látásromlást, látótérkiesést és egyéb kompressziós tüneteket okoznak. Általában sporadikus megjelenésúek, mindössze 4-5\%-ban fordul elő familiaris formájuk [6].

$\mathrm{Az}$ agyalapimirigy-daganatok csoportosíthatók méretük, hormontermelésük és agresszivitásuk alapján. Az l cm átmérőjünél kisebb adenomákat micro-, míg az ennél nagyobbakat macroadenomáknak nevezzük. Funkcionális alapon elkülönítjük a hormont termelő és a nem funkcionáló daganatokat. Az agyalapi mirigy adenomáinak $\mathrm{kb}$. fele prolactinoma, harmada pedig nem funkcionáló daganat. A növekedési hormont termelő (szomatotrop) adenomák kb. 10\%-ot, az ACTH-termelő (kortikotrop) daganatok 1-2\%-ot tesznek ki. Az FSH-t, LH-t (gonadotrop) vagy TSH-t termelő (tireotrop) adenomák ennél is ritkábbak. Egyes tumorok többféle hormont is termelhetnek (plurihormonális adenoma). Nem funkcionáló adenomákról akkor beszélünk, amikor a tumor nem juttat hormonokat a véráramba, vagy az nem okoz klinikai tüneteket, ám a szövettani vizsgálat alapján ezek egy részében immunhisztokémiai pozitivitás igazolható valamelyik hormonra, ami sejteti a tumor eredetét. A teljesen csendes („null cell”) adenomák szövettani vizsgálata minden hormonra negatív [7]. Az agyalapimirigy-adenomák becsült gyakorisága $16,7 \%$, a klinikailag releváns esetek aránya azonban jóval alacsonyabb, megközelítóleg 1:1016 [8]. Gyakoriságuk ellenére a sporadikusan előforduló daganatok kialakulásának molekuláris mechanizmusát még kevésbé tárták fel.

Mai tudásunk alapján az agyalapimirigy-daganatok monoklonális tumorok, ennek ellenére jóindulatúak, lassan növekednek, és csak nagyon ritkán képeznek áttétet, bár alkalmanként lokálisan invazív viselkedést mutatnak [9]. A neuroendokrin tumorokban vagy egyéb szolid tumorokban megtalálható gyakori génmutációk (PKC, RAS, P53, RB, KRAS, EGFR, VEGFR) nem jellemzőek rájuk.

A családi halmozódású daganatokkal összehasonlítva, amelyeknél a legtöbb esetben ismert a csírasejtesen megjelenő genetikai eltérés (legtöbbször mutáció), sporadikus esetek hátterében álló mutációk nem jellemzőek. MENl-gén-mutációt a sporadikus daganatok 0,6-2,6\%ában, $A I P$-mutációt nagyjából a 3\%-ukban, GNASI-mutációt pedig a növekedési hormont termelő daganatok 27-43\%-ában találnak szöveti szinten [9-11].

A kromoszóma-rendellenességeket tekintve az agyalapimirigy-daganatok 21-53\%-ában írtak le caryotypuseltérést $[12,13]$. Ezek az eltérések azonban egyszerúek, általában egy daganatban egyfélék, a legtöbbször számbeliek, ritkán kromoszómaátrendeződések. A leggyakrabban érintett kromoszómák gyakorisági sorrendben a 7 -es, a 9-es, a 12 -es és a 20-as kromoszóma. Felmerül az ezekben a lokalizációkban található EGFR-, PACAP-, VIPR 1-, VIPR2-gén tumorgenezisben betöltött szerepe, melyet azonban a mai napig nem sikerült egyértelmúen igazolni, így e locusok és az általuk kódolt gének pontos szerepének tisztázására további vizsgálatok szükségesek $[12,13]$.

Összességében tehát elmondható, hogy a klasszikus génmutációk és kromoszómaeltérések nem jellemzőek az agyalapimirigy-daganatokra, érdekes módon azonban az epigenetikai szabályozás (hipermetiláció, miRNS-ek) szerepe gyakran igazolt e benignus tumorok kialakulásában.

Ezek alapján úgy vélik, hogy az agyalapimirigy-daganatok kialakulásához több eltérés együttes jelenléte vezet [13]. Ritka esetekben a fent említett gének mutációi (GNAS1, mely a cAMP-útvonal konstitucionális aktivációját okozza, vagy $M E N I)$ számos tumorszuppresszor hipermetilációja vagy elvesztése (pl. p16, RB), a PTTGonkogén fokozott kifejeződése, valamint a miRNS-hatások is szükségesek. Mivel az agyalapimirigy-adenomákban a napjainkban alkalmazott daganatellenes terápiák (KRAS, EGFR) alapját jelentő gént vagy jelátviteli útvonalat érintő genetikai eltérések nem jellemzőek, ezek az új, célzott terápiák egyelőre az agyalapimirigy-daganatok esetén nem jönnek szóba. Kivételnek tekinthetó a szomatosztatinreceptort célzó kezelés növekedési hormont termelő daganatok esetén. 


\section{miRNS-expressziós eltérések az agyalapimirigy-daganatokban}

Az utóbbi években egyre inkább elótérbe kerül a miRNS-ek lehetséges szerepe a daganatos megbetegedésekben. Számos tumorszövetben írtak már le megváltozott miRNS-expressziós mintázatot [14]. Több esetben megfigyelték, hogy ez nemcsak a tumor jelenlétére, de szövettani típusára, stádiumára és viselkedésére is utalhat, ezzel segítve a diagnózist és az optimális terápia meghatározását [15].

Elsősorban állatmodellek vizsgálata alapján tudjuk, hogy a miRNS-ek fontosak az agyalapi mirigy fiziológiás múködésében, és hiányuk agyalapimirigy-rendellenességhez vezet [16-20], ám konkrét szerepükről kevés adat áll rendelkezésre. Egér esetében a miRNS-ek éréséhez szükséges Dicer enzim specifikus kiütése a gonadotrop sejtekben csökkentette a gonadotropinok szintjét, és megváltozott reprodukciós funkciókat, csökkent fertilitást okozott hím egereknél [21]. Egy másik tanulmányban az egér központi idegrendszerének különbözó részeit vizsgálva sikerült agyalapimirigyre specifikus miRNS-eket azonosítani [22]. Amellett, hogy a miRNSeknek az emberben is fontos szerepük van a normál mirigy fejlődésében $[19,23,24]$ és hormontermelésében [25-31], az elmúlt években egyre több humán vizsgálat támasztja alá azt is, hogy részt vehetnek az adenomák kialakulásában és növekedésében [32-35].

$\mathrm{Az}$ agyalapi mirigy daganataival kapcsolatban a miRNS-ek szerepe akkor merült fel, amikor kiderült, hogy az adenomaszövetekben gyakran megfigyelhető deletio a 13-as kromoszóma 14q-karján a miR-15a és a miR-16-1 csökkent expressziójához vezet, s ezáltal felelőssé tehető az adenomák agresszivitásáért [36, 37]. Kimutatták, hogy ezen miRNS-ek expressziója negatív összefüggésben áll a tumormérettel, és a p43 gátlásán keresztül tumorszuppresszor szerepük lehet, így feltételezték, hogy csökkent expressziójuk részt vesz az adenomák progreszsziójában [38]. Ezt követően jelentek meg az agyalapimirigy-daganatokban előforduló miRNS-eket nagy áteresztő́képességú technikákkal elemző vizsgálatok eredményei. Bottoni és mtsai voltak az elsők, akik microarray használatával összehasonlították az adenomaszövetek miRNS-expressziós mintázatát a normál agyalapi mirigy szövetével [39]. Az összesen 30 eltérően expresszálódó miRNS közül 29 alapján prediktálható volt a tumor szövettani típusa az ACTH-t, GH-t, PRL-t termelő, valamint a hormont nem termelő adenomákban. A hormont nem termelő adenomák között 6 miRNS (miR-138, miR-140, miR-30b, miR-30c, miR-99a, miR-99b) eltérően fejeződött ki a micro- és macroadenomákban. Az azonosított miRNS-ek egy része részt vesz a sejtosztódásban vagy az apoptózisban, valamint a prediktált és validált targetjei között sok transzkripciós faktor, onkogén és olyan gének vannak, amelyeknek szerepük van az angiogenezisben és a metasztázisok képzésében.
ACTH-termelő daganatokban Amaral és mtsai olyan, a normálszövethez képest csökkent expressziójú miRNSeket azonosítottak, melyek megváltozott kifejeződését már más tumorokkal kapcsolatban is leírták. Kimutatták továbbá, hogy a miR-141-et gyengén expresszáló ACTH-termelő adenomák esetében nagyobb a sebészeti eltávolítás utáni gyógyulás aránya [40]. Egy másik munkacsoport szintén ACTH-termelő agyalapimirigy-daganatok vizsgálata során kimutatta, hogy a miR-122 és a miR-493 erősebben fejeződik ki carcinomában, mint adenomában és normálszövetben, ami arra utal, hogy ezeknek a miRNS-eknek szerepük lehet a malignitás kialakulásában is [41].

Butz és mtsai a nem funkcionáló adenomákra és normálszövetekre jellemző miRNS-mintázatot vizsgálták, amelynek alapján az adenoma jól elkülöníthető volt az egészséges szövettől [42]. Lehetséges összefüggést mutattak ki a miRNS-ek expressziója és a klinikai változók között. Tizennyolc miRNS-t azonosítottak, melyek expressziója negatívan korrelált a tumormérettel. Ezek közül 6 miRNS (miR-450b-5p, miR-424, miR-503, miR542-3p, miR-629, miR-214) expressziója csökkent, míg egy miRNS-é (miR-592) nőtt a daganatokban a normálszövethez képest. Hasonló megállapítást tettek Mao és $m$ tsai, akik GH-termelő adenomákban 52 eltérően expresszálódó miRNS-t azonosítottak a normálszövethez képest, melyek közül 9 (miR-184, miR-524-5p, miR629, miR-766, miR-124, miR-222, miR-32, miR-744, miR-765) alkalmas lehet a macroadenomák microadenomáktól való elkülönítésére [43].

\section{A miRNS-ek által érintett jelátviteli útvonalak az agyalapimirigy-daganatokban}

A miRNS-ek hatásukat célmolekuláik poszttranszkripcionális szabályozása révén fejtik ki. Egy miRNS-nek a bázispárosodás szabályai szerint több célgénje is van, és egy célmolekula kifejeződését számos miRNS is szabályozhatja. A biológiai funkciók hátterében álló mechanizmusokat a sejten belüli jelátviteli útvonalakkal lehet a leginkább jellemezni, így a miRNS-ek szabályozó szerepét nemcsak egy-egy génhez (1. táblázat) [34, 42, 44-59], hanem egy-egy jelátviteli útvonalhoz is lehet rendelni.

\section{A TGFß-jelátvitel és a miRNS-ek kapcsolata}

Butz és mtsai kutatásaikkal azonosított miRNS-ek in silico útvonal-analízisével feltérképezték azokat a jelátviteli utakat, amelyek érintettek az agyalapimirigy-adenomák patogenezisében. Ezek közül a legjelentősebbnek a TGF $\beta$-útvonal mutatkozott [42]. A TGFß-jelátvitel egy evolúciósan erősen konzervált útvonal, melynek az embrionális fejlődéstól kezdve fontos szerepe van olyan alapvető folyamatok során, mint a sejtnövekedés, sejtdifferenciálódás, szervfejlődés és az apoptózis. Az útvonal tagjainak megváltozott expressziója különböző típusú 
1. táblázat Agyalapimirigy-adenomákban kísérletesen validált miRNS-ek és célmolekuláik daganattípusonként

\begin{tabular}{|c|c|c|c|c|}
\hline miRNS & $\begin{array}{l}\text { Expresszió- } \\
\text { változás }\end{array}$ & $\begin{array}{l}\text { Adenoma } \\
\text { típusa }\end{array}$ & Célgén & $\begin{array}{l}\text { Refe- } \\
\text { rencia }\end{array}$ \\
\hline $\begin{array}{l}\operatorname{miR}-128 \mathrm{a}, \\
\text { miR-155, } \\
\text { miR-516-3p }\end{array}$ & emelkedett & NFA & WEE1 & [44] \\
\hline miR-140-5p & emelkedett & NFA & $S M A D 3$ & [42] \\
\hline miR-524-5p & csökkent & NFA & PTTGIIP & {$[45]$} \\
\hline $\begin{array}{l}\operatorname{miR}-424 \\
\text { miR-503 }\end{array}$ & csökkent & NFA & $C D C 25 A$ & {$[46]$} \\
\hline miR-26b & emelkedett & $\mathrm{GH}$ & PTEN & {$[34]$} \\
\hline miR-128 & csökkent & $\mathrm{GH}$ & $B M I 1$ & {$[34]$} \\
\hline $\begin{array}{l}\text { miR-34b, } \\
\text { miR-548c-3p }\end{array}$ & csökkent & $\mathrm{GH}$ & $\begin{array}{l}H M G A 1, \\
H M G A 2\end{array}$ & {$[47]$} \\
\hline miR-326 & csökkent & $\mathrm{GH}$ & $\begin{array}{l}H M G A 2, \\
E 2 F 1\end{array}$ & {$[47]$} \\
\hline $\begin{array}{l}\operatorname{miR}-432 \\
\operatorname{miR}-570\end{array}$ & csökkent & $\mathrm{GH}$ & $H M G A 2$ & {$[47]$} \\
\hline miR-603 & csökkent & $\mathrm{GH}$ & $E 2 F 1$ & {$[47]$} \\
\hline miR-34 & & $\mathrm{GH}$ & $A I P$ & {$[48]$} \\
\hline $\operatorname{miR}-410$ & csökkent & $\mathrm{FSH} / \mathrm{LH}$ & CCNBI & [49] \\
\hline miR-26a & emelkedett & ACTH & PRKCD & {$[50]$} \\
\hline miR-200c & emelkedett & PRL & PTEN & {$[51]$} \\
\hline miR-26a & emelkedett & $\begin{array}{l}\text { NFA, GH, } \\
\text { ACTH, PRL }\end{array}$ & PLAGI & [52] \\
\hline $\begin{array}{l}\text { miR-15, miR-16, } \\
\text { miR-26a, } \\
\text { miR-196a2 }\end{array}$ & csökkent & $\begin{array}{l}\text { NFA, GH, } \\
\text { PRL }\end{array}$ & $\begin{array}{l}H M G A 1, \\
H M G A 2\end{array}$ & {$[53]$} \\
\hline $\operatorname{miR}-23 b$ & csökkent & $\begin{array}{l}\text { NFA, FSH/ } \\
\text { LH, GH }\end{array}$ & $H M G A 2$ & {$[54]$} \\
\hline miR-130b & csökkent & $\begin{array}{l}\text { NFA, FSH/ } \\
\text { LH, GH }\end{array}$ & CCNA2 & {$[54]$} \\
\hline miR-107 & emelkedett & NFA, GH & $A I P$ & {$[55]$} \\
\hline let-7 & csökkent & $\begin{array}{l}\text { FHS/LH, } \\
\text { ACTH, PRL }\end{array}$ & $H M G A 2$ & {$[56]$} \\
\hline miR-106b & emelkedett & $\begin{array}{l}\text { invazív } \\
\text { (NFA, GH, } \\
\text { ACTH, } \\
\text { PRL) }\end{array}$ & PTEN & {$[57]$} \\
\hline miR-145 & csökkent & invazív & AKT3 & {$[58]$} \\
\hline $\begin{array}{l}\operatorname{miR}-132, \\
\operatorname{miR}-15 a / 16\end{array}$ & csökkent & invazív & SOX5 & [59] \\
\hline
\end{tabular}

ACTH = adrenokortikotrop hormon; FSH = folliculusstimuláló hor mon; $\mathrm{GH}=$ növekedési hormon; $\mathrm{LH}=$ luteinizáló hormon; NFA = nem funkcionáló, hormonálisan inaktív hypophysisadenoma; PRL = prolaktin

daganatok kialakulásához vezethet. A TGFß-útvonal több szinten gátolja a sejtproliferációt. Tagjai között vannak tumorszuppresszorok és onkogének is. Általánosan elfogadott, hogy a TGFß-jelátvitelnek a tumorgenezis elején tumorszuppresszor hatása van, majd egy idő után, bizonyos szignálok hatására ez átfordul, és tumorpromoterként viselkedik [60].
A TGF $\beta$ jelátviteli útvonalban részt vevő (TGF $\beta$, TGFß-receptor, SMAD) molekulák génmutációja agyalapimirigy-daganatokban nem jellemző [61-63], azonban a jelpálya szinte összes tagja poszttranszkripcionális szabályozás alatt áll. A TGFß jelátviteli útvonal és a miRNS-ek közti kísérletesen validált interakciók arra utalnak, hogy a miRNS-ek több szinten befolyásolják a jelátvitelt. Emellett a TGF $\beta$-útvonal erôsíti a miRNS-ek érését, így kétirányú funkcionális kapcsolatról beszélhetünk, melynek bizonyítéka, hogy TGFß-kezelésre több miRNS expressziója is megváltozik [64-67].

A TGFß-útvonal érintettségét továbbvizsgálva kiderült, hogy az útvonal több fontos szereplőjének $S M A D 3, S M A D 6$ és $S M A D 9$ - az expressziója csökkent az adenomákban az ép szövethez képest. A $S M A D 3$ expressziója összefüggést mutatott a tumormérettel, valamint negatívan korrelált számos miRNS expressziójával. Több olyan miRNS került azonosításra, amelyek lehetséges célgénje a SMAD3 (1. táblázat) [42]. Ezek közül a miR-140-et egér-fibroblastsejtben már korábban validálták [68]. Valószínűsíthető tehát, hogy a nem funkcionáló adenomákban a miRNS-ek többek között a SMAD3 gátlásán keresztül megváltoztatják a TGFß jelátviteli útvonal múködését, aminek szerepe lehet az adenomák patogenezisében.

\section{A miRNS-ek általi sejtciklus-reguláció agyalapimirigy-tumorokban}

A sejtciklus regulációjának elromlása kritikus a tumorképződés és a tumorprogresszió szempontjából. Az agyalapimirigy-daganatok 28-70\%-ában (a daganat típusától és invazív készségétől függően) írták le a pRB- és a pl6-fehérjék csökkent kifejeződését promoter hipermetiláció miatt vagy a különböző ciklinmolekulák fokozott expreszszióját [69]. Mivel e molekulák mutációja nem jellemző agyalapimirigy-daganatokban, itt is felmerül a miRNS-ek mint további epigenetikai szabályozó tényezők szerepe.

Elsőként Bottoni és mtsai vetették fel a miR-15a és a miR-16-1 lehetséges tumorszuppresszor szerepét agyalapimirigy-adenomákban, melyek potenciálisan célozzák a sejtciklus Gl/S átmenetének szabályozásában részt vevő ciklin-Dl-et [38].

A sejtciklus másik, G2/M szabályozó pontján ható WEEl-kináz tumorszuppresszor szerepét nemrég azonosították. A WEEl a CDKl-et foszforilálja, ezáltal gátolja annak aktivitását, és így megakadályozza a sejt mitózisba lépését. A WEEl-fehérje expresszióját vizsgálva kiderült, hogy a hormont nem termelö és a GH-termelő adenomák 50-85\%-ában csökkent a kifejeződése a normálszövethez képest. Komplex bioinformatikai és in vitro kísérleti módszerrel sikerült igazolni a miR-128a, a miR-516-3p és a miR-155 szerepét a WEEl-fehérje kifejeződésének szabályozásában (1. táblázat) [44].

Kiegészítve és kiterjesztve korábbi vizsgálatainkat, szisztematikusan megvizsgálva a $\mathrm{G} 2 / \mathrm{M}$ átmenetben részt vevő gének expressziójának szabályozását nem 
funkcionáló agyalapimirigy-daganatokban, a 46 vizsgált gén közül számos eltérő expressziót mutatott, melyek közül a CDC25-család tagjainak miRNS-ek általi szabályozására derült fény [46]. A CDC25-családba tartozó foszfatázok a CDKl-ciklin-B komplex defoszforilációja révén a $\mathrm{G} 2 / \mathrm{M}$ ellenőrző ponton segítik a sejt mitózisba lépését. Hatásuk tehát éppen ellentétes a WEEl-ével. A CDC25A emelkedett expressziót mutatott mRNS- és fehérjeszinten is a nem funkcionáló adenomákban a normál agyalapimirigy-szövethez képest, és expressziója korrelált a tumormérettel is. A CDC25A-t célzó miRNS-ek közül négy esetén mértek csökkent expressziót a tumoros szövetben (miR-449a, miR-449b, miR-424, miR-503), és ezekből kettő (miR-424, miR-503) negatív korrelációt mutatott a tumormérettel, valamint a $C D C 25 A$ expressziójával is, ami erősíti jelentőségüket az adenoma patogenezisében (1. táblázat) [46].

Mindezen eredmények arra utalnak, hogy a G2/M átmenet aktivációja felerősödik az agyalapimirigy-adenomákban, és ebben a miRNS-ek kulcsszerepet játszanak.

\section{A miR NS-ek által szabályozott HMGA-fehérjék komplex szerepe jelátviteli utak befolyásolásában}

A HMGA (High Mobility Group A) géncsaládba tartozó gének (HMGA1, HMGA2) olyan, nem hiszton fehérjéket kódolnak, melyek a kromatinszerkezet megváltoztatása révén befolyásolják más gének transzkripcióját. Szerepük van a sejtosztódás és a sejtciklus szabályozásában. A TP53-on keresztül befolyásolják a DNS-károsodás jelátviteli útvonalat és az apoptózist. A $S M A D 1,-3$, -4 és -5-molekulákkal való interakció révén pedig részt vesznek a TGFß-jelátvitel regulációjában is.

Lehetséges szerepük az agyalapimirigy-adenomák patogenezisében azáltal merült fel, hogy a HMGAl-et vagy a $H M G A 2$-t túlexpresszáló egérben növekedési hormont és prolaktint termelő adenoma alakult ki [70, 71]. Több munkacsoport is leírta a HMGA-fehérjék emelkedett expresszióját humán agyalapimirigy-adenomákban $[39,40]$. Qian és mtsai összefüggést találtak a $H M G A 2$ expressziója és a tumor típusa, mérete, invazivitása, stádiuma és agresszivitása (a Ki-67-index alapján) között [56]. Egyedül prolactinomákban igazolható a HMGA fokozott kifejeződéséért felelős kromoszómaeltérés (12-es triszómia). A többi adenomatípusban a gének fokozott expresszióját egyelöre egyedül a miRNSeknek tulajdonítják [9]. Igazolták a let-7 miRNS és a $H M G A 2$ expressziója közötti negatív korrelációt. Azóta számos miRNS-ról igazolták, hogy célozza a HMGAIvagy $H M G A 2-3$ 'UTR-eket (1. táblázat) $[47,53,54$, 56]. A szabályozás komplexitását jól mutatja, hogy a HMGA-fehérjék kapcsolatban vannak a JUN/Fos és a p53 indukálta apoptózis-útvonallal, ezáltal a DNS-hibajavítással, gyulladásos folyamatokkal, az epithelialis-mesenchymalis átmenettel (EMT) és a sejtciklusfehérjékkel is. Így csak a HMGA-fehérjék befolyásolásával a miRNSek megváltozott expressziója számos útvonalat érint.

\section{Terápiás választ jelző miRNS-ek}

A gyógyszeres terápia prolactinomák esetében az elsőként választandó terápiás beavatkozás, míg GH-t, ACTH-t, gonadotropint vagy TSH-t termelő daganatok esetében a sebészi beavatkozás jelenti a fő kezelési stratégiát. Az utóbbi évek kutatásai egyre inkább felhívják a figyelmet olyan miRNS-ekre, melyek eltérően fejeződnek ki gyógyszeres kezelés előtt és után, és ezáltal expressziójuk esetleg szóba jöhet a terápiás válasz monitorizálásában.

Először 2007-ben Bottoni és mtsai írtak le olyan miRNS-eket (miR-134, miR-148, miR-155, miR-29b, miR-29c, miR-200a), melyek eltérően expresszálódtak olyan nem funkcionáló adenomákban, melyeket dopaminagonistával kezeltek, összehasonlítva a kezeletlenekkel [39]. Egy másik tanulmányban bromokriptinnel kezelt és nem kezelt prolactinomás betegeket hasonlítottak öszsze. A két csoport között 151 miRNS-expressziós eltérést találtak, melyek közül a miR-206, a miR-516b és a miR-550 emelkedett, és a miR-671-5p csökkent expresszióját sikeresen validálták [72].

GH-termelő adenomákban a lanreotidkezelés hatására megváltozott miRNS-profilt igazoltak; a kezelés hatására 7 miRNS fokozott (miR-183, miR-193a-5p, miR-222, miR-516b, miR-524-5p, miR-601, miR-99b), 4 pedig csökkent (miR-124, miR-32, miR-574-5p, miR-96) expressziót mutatott. Sót azonosítottak 7 miRNS-t, melyek különböztek (miR-125b, miR-886-5p emelkedett, miR-125a-5p, miR-198, miR-503, miR-524-5p és miR630 csökkent) a szomatosztatinanalóg-kezelésre reagáló vs. nonreszponder betegek daganatszöveteiben [43]. Figyelembe véve, hogy az azonosított miRNS-ek közül többnek szerepe van a sejtproliferációban, az apoptózisban és a tumorképződésben, a szerzők feltételezik, hogy az eltérően kifejeződő miRNS-ek szerepet játszhatnak a GH-termelő adenomák transzformációjában, és felhívják a figyelmet arra, hogy ezek targetjeinek vizsgálata segíthet a patogenezis pontosabb megértésében [43]. Emellett, ha ezeknek a vizsgálatoknak az eredményeit megerősítik nagyobb esetszámon és hosszabb kezelésen áteső betegeken, akkor a miRNS-mintázat alapján akár megbecsülhetô lehet, hogy egy beteg reagálni fog-e a szomatosztatinanalóg-kezelésre [73].

Ezek az eredmények elsőként támasztják alá, hogy a miRNS-eknek szerepük lehet a szomatosztatinanalóg- és dopaminagonista-kezelésre adott válasz szabályozásában, valamint amennyiben a közeljövőben sikerül jobban megismerni az ezek mögött álló mechanizmusokat, az akár terápiás választ jelző biomarkerek azonosítását is lehetővé tenné.

\section{A miRNS-ek mint terápiás szerek}

A miRNS-terápia kifejlesztése - más gyógyszerekhez hasonlóan - többlépcsős folyamat. Elsőként szükséges meghatározni az eltérően expresszálódó miRNS-eket, majd szerepüket in vitro funkcionális és in vivo állatkísér- 


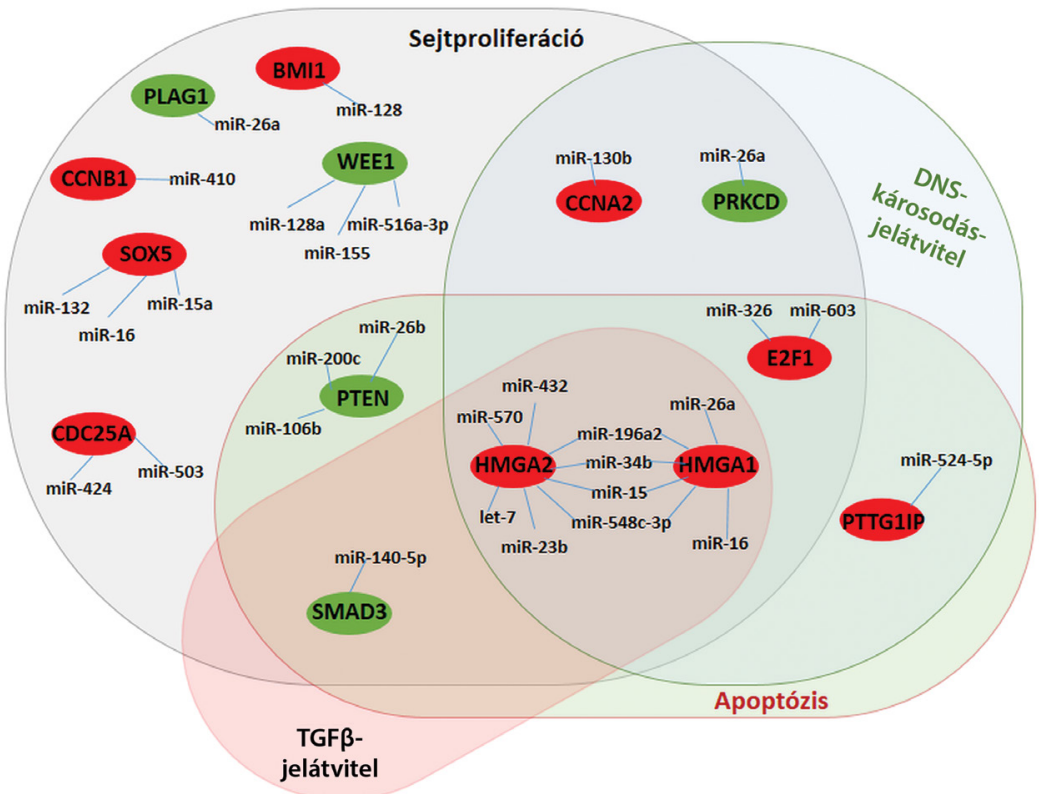

1. ábra

Az agyalapi mirigy daganataiban a miRNS-ek által szabályozott gének szerepe különböző jelátviteli útvonalakban, sejtfunkciókban. A gének kategóriába sorolása génontológiai analízissel (Gene Ontology Analysis) történt. A molekulaszínek a génexpressziót jelölik; piros: fokozott, zöld: csökkent kifejeződés

letekkel validálni. Ezt követik a farmakológiai vizsgálatok a miRNS/anti-miRNS szisztémás/lokális célba juttatására vonatkozóan, valamint a farmakokinetikai, -dinámiás (felszívódás, eloszlás, metabolizmus, kiválasztás, toxikológiai) vizsgálatok [74]. Csak mindezek után következhetnek a klinikai kipróbálás lépései.

Egyre több opció válik lehetővé az elveszett/csökkent mennyiségben jelen lévő miRNS-ek pótlásának vagy a fokozottan expresszálódó miRNS-ek gátlásának gyakorlati megvalósításához. Olyannyira, hogy jelenleg számos miRNS- „gyógyszer” van már kipróbálás alatt preklinikai, fázis I. és fázis II. vizsgálatokban. A legelőrehaladottabb fázisban a májspecifikus miR-122-ellenes anti-miR (antagomiR) fejlesztése áll. Mivel a miR-122 kötődik a hepatitis C-vírus genomjához, és serkenti a virális transzlációt és replikációt, gátlásával jelentősen csökkenthető a vírus kópiaszáma.

A gyakorlatban a miRNS-ek gátlására antiszensz miRNS-eket (antagomiR) alkalmaznak. A hagyományos nukleinsav-szerkezet érzékeny az RNázokkal szemben, a nukleinsavak kémiai módosításával azonban stabilabbá tehetők ezek a kis RNS-molekulák a szervezetben (pl. LNA-locked nucleic acid, 2'-O-metiláció, részleges foszforotioátváz, PNA-peptid structured polimer), s ezáltal szisztémás alkalmazásuk is lehetővé válik. Az antagomiRek mellett a miRNS-ek gátolhatók ún. „miRNS-szivacsokkal” (miRNA sponge) vagy miRNS-maszkolással („miRNA masking”). A miRNS-szivacsok olyan hoszszabb nukleinsavak, melyek az adott miRNS-re számos komplementer kötőhellyel rendelkeznek, így gyakorlatilag elvonják a miRNS-t a fiziológiás célmolekulájuktól. A miRNS-maszkolás lényege pedig, hogy a miRNSmaszk a regulált gén 3'UTR-jében található miRNS-kö- tőhelyeket lefedve kioltja a miRNS-ek hatását az adott génre. A miRNS-szivacsok tehát az „endogén” miRNSek akár több génre kifejtett hatását gátolják, a miRNSmaszkok pedig akár több miRNS-nek egy adott célgénre kifejtett hatását blokkolhatják $[74,75]$.

Az agyalapi mirigy daganataiban a miRNS-ek mint terápiás célpontok vizsgálata még gyerekcipőben jár. Mindöszsze néhány in vivo állatkísérletes modellről vannak elérhető adatok az irodalomban. Zhen és mtsai a tumorszuppresszor miR-524-5p szerepét vizsgálták xenograftmodellen. Létrehoztak egy miR-524-5p-t fokozottan expresszáló agyalapimirigy-eredetű folliculostellate sejtklónt, melyből egérben képzett xenografttumorok csökkent tumornövekedést mutattak a kontrollsejtekhez képest [45].

Egy másik kutatócsoport a valós miRNS-terápiához közelebb álló kísérletes elrendezéssel próbálkozott. Növekedési hormont termelő adenomasejtekból képzett xenografttumorral rendelkező egereken vizsgálták a szisztémásan adott miRNS-ek hatását. Négy miRNS (miR-329, miR300, miR-381, miR-655) egyedi, valamint kombinált adása csökkentette a tumorméretet a kontrollkezeléshez képest, és kimutatták, hogy ezek a miRNS-ek a PTTG1gén szabályozásán keresztül fejtették ki hatásukat [76]. Mivel a PTTGl az agyalapimirigy-adenomák kb. 95\%ában onkogénszerepet tölt be, ezek a kísérletes adatok rendkívül biztatóak egy potenciális, jövőben alkalmazható miRNS-alapú terápia kifejlesztése szempontjából.

\section{Következtetés}

A miRNS-ek mint poszttranszkripcionális regulátorok fontos szerepet töltenek be számos sejtfunkció szabályozásában, és ezáltal az agyalapimirigy-adenomák kialaku- 
lásában is szerepet játszhatnak. Eltérő expressziójuk patogenetikai szerepének megismerésével még közelebb kerülhetünk a daganatok kialakulásának megértéséhez. A miRNS-ek ezen túlmenően azonban potenciális diagnosztikus biomarkerként is szolgálhatnak azáltal, hogy kifejeződésük eltér a macro- és microadenomák között, a különböző sejttípusok között, valamint a terápiára adott válasz indikátoraként is felvetődik lehetséges alkalmazásuk. A további kutatások egyre inkább a miRNS-eknek a terápiában betöltött szerepére fókuszálnak, és feltételezhetően az agyalapi mirigy daganatainak esetében is alkalmazható terápiás stratégiát jelenthetnek.

Anyagi támogatás: E munkát a Nemzeti Kutatási, Fejlesztési és Innovációs Hivatal dr. Butz Henriett által elnyert pályázata - NKFIH (OTKA PD 116093) és a Németh Kinga által elnyert, az Emberi Erőforrások Minisztériuma (EMMI) Nemzeti Tehetség Program (NTP) Egyéni Fejlesztési Ösztöndíj (NTP-EFÖ-P-15-0379) támogatta.

Szerzői munkamegosztás: Az összefoglaló közlemény megírásában valamennyi szerző részt vett, végleges változatát mindegyik szerző elolvasta és jóváhagyta.

Érdekeltségek: A szerzőknek nincsenek érdekeltségeik.

\section{Köszönetnyilvánítás}

A szerzốk dolgozatukkal emlékeznek $D r$. Rácz Károly professzor úrra, a Semmelweis Egyetem Endokrinológiai Genetikai Laboratóriumának korábbi vezetôjére a tudományos munka és téma iránti érdeklődés kialakításáért és a laboratóriumi háttér biztosításáért. Köszönettel tartozunk neki a kritikus, tudományos szemlélet kialakításáért és a mindenkor rendelkezésre álló szakmai és emberi támogatásáért.

\section{Irodalom}

[1] Bartel DP. MicroRNAs: genomics, biogenesis, mechanism, and function. Cell 2004; 116: 281-297.

[2] Krol J, Loedige I, Filipowicz W. The widespread regulation of microRNA biogenesis, function and decay. Nat Rev Genet. 2010; 11: 597-610.

[3] Rajewsky N. microRNA target predictions in animals. Nat Genet. 2006; 38: S8-S13

[4] Lewis BP, Burge CB, Bartel DP. Conserved seed pairing, often flanked by adenosines, indicates that thousands of human genes are microRNA targets. Cell 2005; 120: 15-20.

[5] Daly AF, Burlacu MC, Livadariu E, et al. The epidemiology and management of pituitary incidentalomas. Horm Res. 2007; 68(Suppl 5): 195-198.

[6] Daly AF, Tichomirowa MA, Beckers A. The epidemiology and genetics of pituitary adenomas. Best Pract Res Clin Endocrinol Metab. 2009; 23: 543-554.

[7] Daly AF, Rixhon M, Adam C, et al. High prevalence of pituitary adenomas: a cross-sectional study in the province of Liège, Belgium. J Clin Endocrinol Metab. 2006; 91: 4769-4775.

[8] Tichomirowa MA, Daly AF, Beckers A. Familial pituitary adenomas. J Intern Med. 2009; 266: 5-18.

[9] Jiang X, Zhang X. The molecular pathogenesis of pituitary adenomas: an update. Endocrinol Metab. (Seoul) 2013; 28: 245254 .
[10] Lecoq AL, Kamenický P, Guiochon-Mantel A, et al. Genetic mutations in sporadic pituitary adenomas - what to screen for? Nat Rev Endocrinol. 2015; 11: 43-54.

[11] Yamasaki H, Mizusawa N, Nagahiro S, et al. GH-secreting pituitary adenomas infrequently contain inactivating mutations of PRKARIA and LOH of 17q23-24. Clin Endocrinol. 2003; 58: $464-470$.

[12] Larsen JB, Schrøder HD, Sørensen AG, et al. Simple numerical chromosome aberrations characterize pituitary adenomas. Cancer Genet Cytogenet. 1999; 114: 144-149.

[13] Bello MJ, de Campos JM, Kusak ME, et al. Chromosomal abnormalities in pituitary adenomas. Cancer Genet Cytogenet. 2001; 124: 76-79.

[14] Farazi TA, Hoell JI, Morozov P, et al. MicroRNAs in human cancer. Adv Exp Med Biol. 2013; 774: 1-20.

[15] Chen Y, Stallings RL. Differential patterns of microRNA expression in neuroblastoma are correlated with prognosis, differentiation, and apoptosis. Cancer Res. 2007; 67: 976-983.

[16] Yuan B, Han DX, Dai LS, et al. A comprehensive expression profile of microRNAs in rat's pituitary. Int J Clin Exp Med. 2015; 8: 13289-13295.

[17] Li H, Xi Q, Xiong Y, et al. A comprehensive expression profile of microRNAs in porcine pituitary. PLoS ONE 2011; 6: e24883.

[18] Schneeberger M, Altirriba J, García A, et al. Deletion of miRNA processing enzyme Dicer in POMC-expressing cells leads to pituitary dysfunction, neurodegeneration and development of obesity. Mol Metab. 2012; 2: 74-85.

[19] Zhang Z, Florez S, Gutierrez-Hartmann A, et al. MicroRNAs regulate pituitary development, and microRNA $26 \mathrm{~b}$ specifically targets lymphoid enhancer factor 1 (Lef- 1 ), which modulates pituitary transcription factor 1 (Pit-1) expression. J Biol Chem. 2010; 285: 34718-34728

[20] Choi JW, Kang SM, Lee Y, et al. MicroRNA profiling in the mouse hypothalamus reveals oxytocin-regulating microRNA. J Neurochem. 2013; 126: 331-337.

[21] Wang H, Graham I, Hastings R, et al. Gonadotrope-specific deletion of Dicer results in severely suppressed gonadotropins and fertility defects. J Biol Chem. 2015; 290: 2699-2714.

[22] Bak M, Silahtaroglu A, Møller M, et al. MicroRNA expression in the adult mouse central nervous system. RNA 2008; 14: 432444 .

[23] Zatelli MC, degli Uberti EC. MicroRNAs and possible role in pituitary adenoma. Semin Reprod Med. 2008; 26: 453-460.

[24] Savulescu D, Feng J, Ping YS, et al. Gonadotropin-releasing hormone-regulated prohibitin mediates apoptosis of the gonadotrope cells. Mol Endocrinol. 2013; 27: 1856-1870.

[25] Zhang N, Lin J, Chen J, et al. MicroRNA 375 mediates the signaling pathway of corticotropin-releasing factor $(\mathrm{CRF})$ regulating pro-opiomelanocortin (POMC) expression by targeting mitogen-activated protein kinase 8. J Biol Chem. 2013; 288: 1036110373.

[26] Nemoto T, Mano A, Shibasaki T. miR-449a contributes to glucocorticoid-induced CRF-Rl downregulation in the pituitary during stress. Mol Endocrinol. 2013; 27: 1593-1602.

[27] Ye RS, Xi QY, Qi Q, et al. Differentially expressed miRNAs after $\mathrm{GnRH}$ treatment and their potential roles in FSH regulation in porcine anterior pituitary cell. PLoS ONE 2013; 8: e57156.

[28] Lannes J, L'Hôte D, Garrel G, et al. Rapid communication: A microRNA-132/212 pathway mediates GnRH activation of FSH expression. Mol Endocrinol. 2015; 29: 364-372.

[29] Godoy J, Nishimura M, Webster NJ. Gonadotropin-releasing hormone induces miR-132 and miR-212 to regulate cellular morphology and migration in immortalized L $\beta$ T2 pituitary gonadotrope cells. Mol Endocrinol. 2011; 25: 810-820.

[30] Nemoto T, Mano A, Shibasaki T. Increased expression of miR$325-3 p$ by urocortin 2 and its involvement in stress-induced suppression of LH secretion in rat pituitary. Am J Physiol Endocrinol Metab. 2012; 302: E781-E787.

[31] Lannes J, L'hôte D, Fernandez-Vega A, et al. A regulatory loop between miR-132 and miR-125b involved in gonadotrope cells desensitization to GnRH. Sci Rep. 2016; 6: 31563.

[32] Asa SL, Ezzat $S$. The pathogenesis of pituitary tumours. Nat Rev Cancer 2002; 2: 836-849. 
[33] Butz H. Role of microRNAs in sporadic pituitary tumorigenesis. Doctoral dissertation. [MikroRNS-ek szerepe a hypophysis daganatok patogenezisében. Doktori értekezés.] Semmelweis Egyetem, Klinikai Orvostudományok Doktori Iskola, Budapest, 2010. [Hungarian]

[34] Palumbo T, Faucz FR, Azevedo M, et al. Functional screen analysis reveals miR-26b and miR- 128 as central regulators of pituitary somatomammotrophic tumor growth through activation of the PTEN-AKT pathway. Oncogene 2013; 32: 1651-1659.

[35] Wei Z, Zhou C, Liu M, et al. MicroRNA involvement in a metastatic non-functioning pituitary carcinoma. Pituitary $2015 ; 18$ : 710-721

[36] Pei L, Melmed S, Scheithauer B, et al. Frequent loss of heterozygosity at the retinoblastoma susceptibility gene $(R B)$ locus in aggressive pituitary tumors: evidence for a chromosome $13 \mathrm{tu}-$ mor suppressor gene other than $R B$. Cancer Res. 1995; 55: 1613-1616.

[37] Calin GA, Dumitru CD, Shimizu M, et al. Frequent deletions and down-regulation of micro-RNA genes $m i R 15$ and $m i R 16$ at $13 \mathrm{ql} 4$ in chronic lymphocytic leukemia. Proc Natl Acad Sci USA 2002; 99: 15524-15529.

[38] Bottoni A, Piccin D, Tagliati F, et al. miR-15a and miR-16-1 down-regulation in pituitary adenomas. J Cell Physiol. 2005; 204: 280-285.

[39] Bottoni A, Zatelli MC, Ferracin M, et al. Identification of differentially expressed microRNAs by microarray: A possible role for microRNA genes in pituitary adenomas. J Cell Physiol. 2007; 210: 370-377.

[40] Amaral FC, Torres N, Saggioro F, et al. MicroRNAs differentially expressed in ACTH-secreting pituitary tumors. J Clin Endocrinol Metab. 2009; 94: 320-323.

[41] Stilling G, Sun Z, Zhang S, et al. MicroRNA expression in ACTH-producing pituitary tumors: up-regulation of microRNA-122 and -493 in pituitary carcinomas. Endocrine 2010; 38: 67-75.

[42] Butz H, Likó I, Czirják S, et al. MicroRNA profile indicates downregulation of the TGF $\beta$ pathway in sporadic non-functioning pituitary adenomas. Pituitary $2011 ; 14: 112-124$.

[43] Mao ZG, He DS, Zhou J, et al. Differential expression of microRNAs in GH-secreting pituitary adenomas. Diagn Pathol. 2010; 5: 79

[44] Butz H, Likó I, Czirják S, et al. Down-regulation of Weel kinase by a specific subset of microRNA in human sporadic pituitary adenomas. J Clin Endocrinol Metab. 2010; 95: E181-E191.

[45] Zhen W, Qiu D, Zhiyong C, et al. MicroRNA-524-5p functions as a tumor suppressor in a human pituitary tumor-derived cell line. Horm Metab Res. 2017; 49: 550-557.

[46] Butz H, Németh K, Czenke D, et al. Systematic investigation of expression of $\mathrm{G} 2 / \mathrm{M}$ transition genes reveals CDC25 alteration in nonfunctioning pituitary adenomas. Pathol Oncol Res. 2017; 23: 633-641.

[47] D'Angelo D, Palmieri D, Mussnich P, et al. Altered microRNA expression profile in human pituitary GH adenomas: down-regulation of miRNA targeting HMGAl, HMGA2, and E2Fl. J Clin Endocrinol Metab. 2012; 97: E1128-E1138.

[48] Dénes J, Kasuki L, Trivellin G, et al. Regulation of aryl hydrocarbon receptor interacting protein (AIP) protein expression by MiR-34a in sporadic somatotropinomas. PLoS ONE 2015; 10 e0117107.

[49] Müssnich P, Raverot G, Jaffrain-Rea M-L, et al. Downregulation of miR-410 targeting the cyclin $\mathrm{Bl}$ gene plays a role in pituitary gonadotroph tumors. Cell Cycle 2015; 14: 2590-2597.

[50] Gentilin E, Tagliati F, Filieri C, et al. miR-26a plays an important role in cell cycle regulation in ACTH-secreting pituitary adenomas by modulating protein kinase $\mathrm{C} \delta$. Endocrinology 2013; 154: 1690-1700.

[51] Liao C, Chen W, Fan X, et al. MicroRNA-200c inhibits apoptosis in pituitary adenoma cells by targeting the PTEN/Akt signaling pathway. Oncol Res. 2013; 21: 129-136.

[52] Yu C, Li J, Sun F, et al. Expression and clinical significance of miR-26a and pleomorphic adenoma gene 1 (PLAGl) in invasive pituitary adenoma. Med Sci Monit. 2016; 22: 5101-5108.

[53] Palmieri D, D'Angelo D, Valentino T, et al. Downregulation of $H M G A$-targeting microRNAs has a critical role in human pituitary tumorigenesis. Oncogene 2012; 31: 3857-3865.
[54] Leone V, Langella C, D'Angelo D, et al. Mir-23b and miR-130b expression is downregulated in pituitary adenomas. Mol Cell Endocrinol. 2014; 390: 1-7.

[55] Trivellin G, Butz H, Delhove J, et al. MicroRNA miR-107 is overexpressed in pituitary adenomas and inhibits the expression of aryl hydrocarbon receptor-interacting protein in vitro. Am J Physiol Endocrinol Metab. 2012; 303: E708-719.

[56] Qian ZR, Asa SL, Siomi H, et al. Overexpression of HMGA2 relates to reduction of the let-7 and its relationship to clinicopathological features in pituitary adenomas. Mod Pathol. 2009; 22: $431-441$.

[57] Zheng Z, Zhang Y, Zhang Z, et al. Effect of miR-106b on invasiveness of pituitary adenoma via PTEN-PI3K/AKT. Med Sci Monit. 2017; 23: 1277-1285.

[58] Zhou K, Fan YD, Wu PF, et al. MicroRNA-145 inhibits the activation of the mTOR signaling pathway to suppress the proliferation and invasion of invasive pituitary adenoma cells by targeting AKT3 in vivo and in vitro. Onco Targets Ther. 2017; 10: 16251635.

[59] Renjie W, Haiqian L. MiR-132, miR-15a and miR-16 synergistically inhibit pituitary tumor cell proliferation, invasion and migration by targeting Sox 5 . Cancer Lett. $2015 ; 356$ : 568-578.

[60] Roberts AB, Wakefield LM. The two faces of transforming growth factor $\beta$ in carcinogenesis. PNAS 2003; 100: 8621-8623.

[61] Melmed S. Mechanisms for pituitary tumorigenesis: the plastic pituitary. J Clin Invest. 2003; 112: 1603-1618.

[62] Ikeda H. Mutational analysis of transforming growth factor-beta receptor type II and Smad3 tumor suppressor genes in prolactinomas. Brain Tumor Pathol. 2006; 23: 7-12.

[63] Lebrun JJ. Activin, TGF- $\beta$ and menin in pituitary tumorigenesis. Adv Exp Med Biol. 2009; 668: 69-78.

[64] Davis BN, Hilyard AC, Lagna G, et al. SMAD proteins control DROSHA-mediated microRNA maturation. Nature 2008; 454 : $56-61$.

[65] Butz H, Rácz K, Hunyady L, et al. Crosstalk between TGF- $\beta$ signaling and the microRNA machinery. Trends Pharmacol Sci. 2012; 33: 382-393.

[66] Zhou H, Wang K, Hu Z, et al. TGF- $\beta 1$ alters microRNA profile in human gastric cancer cells. Chin J Cancer Res. 2013; 25: 102111.

[67] Mendias CL, Gumucio JP, Lynch EB. Mechanical loading and TGF- $\beta$ change the expression of multiple miRNAs in tendon fibroblasts. J Appl Physiol (1985). 2012; 113: 56-62.

[68] Pais H, Nicolas FE, Soond SM, et al. Analyzing mRNA expression identifies Smad3 as a microRNA-140 target regulated only at protein level. RNA 2010; 16: 489-494.

[69] Quereda V, Malumbres M. Cell cycle control of pituitary development and disease. J Mol Endocrinol. 2009; 42: 75-86.

[70] Fedele M, Battista S, Kenyon L, et al. Overexpression of the $H M G A 2$ gene in transgenic mice leads to the onset of pituitary adenomas. Oncogene 2002; 21: 3190-3198.

[71] Fedele M, Pentimalli F, Baldassarre G, et al. Transgenic mice overexpressing the wild-type form of the $H M G A 1$ gene develop mixed growth hormone/prolactin cell pituitary adenomas and natural killer cell lymphomas. Oncogene 2005; 24: 3427-3435.

[72] Wang C, Su Z, Sanai N, et al. microRNA expression profile and differentially-expressed genes in prolactinomas following bromocriptine treatment. Oncol Rep. 2012; 27: 1312-1320.

[73] Gadelha MR, Kasuki L, Dénes J, et al. MicroRNAs: Suggested role in pituitary adenoma pathogenesis. J Endocrinol Invest. 2013; 36: 889-895.

[74] Christopher AF, Kaur RP, Kaur G, et al. MicroRNA therapeutics: Discovering novel targets and developing specific therapy. Perspect Clin Res. 2016; 7: 68-74.

[75] Krützfeldt J. Strategies to use microRNAs as therapeutic targets. Best Pract Res Clin Endocrinol Metab. 2016; 30: 551-561.

[76] Liang HQ, Wang RJ, Diao CF, et al. The PTTGl-targeting miRNAs miR-329, miR-300, miR-381, and miR-655 inhibit pituitary tumor cell tumorigenesis and are involved in a p53/ PTTGl regulation feedback loop. Oncotarget 2015; 6: 2941329427.

(Butz Henriett dr., Budapest, Szentkirályi u. 46., 1088 e-mail: butz.henriett@med.semmelweis-univ.hu) 